\title{
Hubungan Lingkungan Belajar Klinik dengan Tingkat Kecemasan Mahasiswa pada Program Pendidikan Ners
}

\author{
Nelwati $^{\text {a }}$,Triyana Harlia Putri ${ }^{\text {a }}$, Atih Rahayuningsih ${ }^{a}$ \\ ${ }^{a}$ Program Studi Ilmu Keperawatan Fakultas Kedokteran Unand \\ E-mail : nelwati.salim@gmail.com
}

\begin{abstract}
Clinical learning environment is the vehicle of clinical learning. However, less supportive clinical environment may trigger anxiety of students while learning. The purpose of the study was to determine the correlation between clinical learning environment relationships and levels of anxiety in student nurses learning Study Program Nursing Science Faculty Medicine Andalas University 2011. This research used the cross sectional approach with 69 students as respondents. The data was collected by applicating two questionnaires SECEE and DASS. The study showed that $49 \%$ of student nurses have a bad clinical learning environment and $56.5 \%$ student nurses have high levels of anxiety being. There was a significant association between the clinical learning environment and levels of anxiety with Spearman rank analysis $p$-value $=0.000$ and $r=-0.769$. Application of mentorship method is needed in any room while having clinical learning in order to increase trustee, self dignity, confidence and competence achievement of students.
\end{abstract}

Key words: clinical learning, clinical environment, anxiety

\begin{abstract}
Abstrak: Lingkungan belajar klinik merupakan wahana pembelajaran klinik. Kurangnya komunikasi dan feedback yang seharusnya terfasilitasi oleh lingkungan klinik menjadi perhatian yang selektif. Tujuan penelitian ini adalah untuk mengetahui hubungan lingkungan belajar klinik dengan tingkat kecemasan pada pembelajaran klinik mahasiswa program Ners Program Studi Ilmu Keperawatan Fakultas Kedokteran Universitas Andalas tahun 2011. Penelitian ini bersifat korelatif dengan pendekatan cross sectional. Penggambilan sampel menggunakan metode total sampling. Jumlah sampel sebanyak 69 orang mahasiswa pada tanggal 21-29 November 2011 dengan menggunakan kuesioner SECEE dan DASS. Hasil analisa data menunjukan $49 \%$ mahasiswa program Ners menyatakan lingkungan belajar klinik buruk dan 56,5\% mahasiswa program Ners memiliki tingkat kecemasan sedang. Didapatkan hasil dari analisis bivariat terdapat hubungan antara lingkungan belajar klinik dengan tingkat kecemasan dengan analisis spearman rank nilai $\mathrm{p}=0,000$ dan $r=-0,769$ dengan arah korelasi negatif, dimana semakin buruk lingkungan belajar klinik akan semakin meningkatkan kecemasan. Perlu penerapan metode mentorship di setiap ruangan tempat praktik selama pembelajaran klinik sehingga dapat meningkatkan kepercayaan, harga diri, kepercayaan diri serta pencapaian kompetensi mahasiswa.
\end{abstract}

Kata kunci: pembelajaran klinik, lingkungan klinik, kecemasan

Pembelajaran merupakan salah satu proses yang ada di pendidikan klinik. Menurut Emilia (2008) pembelajaran adalah suatu proses yang kompleks. Pembelajaran klinik dalam keperawatan merupakan wahana yang memberikan kesempatan kepada mahasiswa untuk menerjemahkan pengetahuan teoritis ke dalam pembelajaran (Emilia, 2008). Menurut Corkhill (1998) dikutip dari Syahreni dan Waluyanti (2007) tujuan pembelajaran klinik adalah mengintegrasikan teori dengan praktik. Hal 
senada yang di ungkapkan oleh Munthe (2009) pembelajaran klinik tidak hanya memberikan kesempatan untuk menerapkan teori-teori yang telah diperoleh dikelas sebelumnya. Selain itu, menurut Reily (2002) pembelajaran klinik juga memberikan kesempatan kepada mahasiswa untuk mengembangkan keterampilan berfikir kritis. Pembelajaran klinik harus ditata sedemikian rupa sehingga mahasiswa mempunyai kemampuan untuk berhubungan dengan masalah nyata tersebut (Syahreni \& Waluyanti, 2007).

Dalam proses pencapaian kompetensi tidak dapat dipisahkan dari rumah sakit pendidikan sebagai wahana pembelajaran klinik. Menurut Emilia (2008) pengertian wahana mempunyai konotasi wadah atau tempat dengan seluruh sumber daya yang secara dinamis ikut berperan, serta sebagai lingkungan belajar klinik yang kondusif bagi pencapaian kompetensi bagi para mahasiswa. Lingkungan klinik yang dipilih penting untuk mencapai objektif dan tujuan praktik klinik dalam sebuah program pendidikan keperawatan (Emilia, 2008).

Lingkungan belajar sangatlah penting karena mempengaruhi pendekatan belajar yang di ambil oleh mahasiswa dan akhirnya akan mempengaruhi pencapaian kompetensi mahasiswa (Emilia, 2008). Lingkungan belajar yang baik adalah lingkungan yang menstimulasi rasa ingin tahu dan kebutuhan untuk mengerti, bukan menstimulasi kegelisahan dan kompetisi (Emilia, 2007). Menurut Reilly dan Oermann (2002) lingkungan klinik kaya akan pengalaman belajar, tetapi lingkungan yang kurang mendukung akan mematahkan semangat belajar peserta didik untuk mencari pengalaman dan akibatnya banyak kesempatan untuk maju hilang. Persepsi mahasiswa terhadap lingkungan belajar dianggap mempunyai pengaruh yang penting pada kualitas hasil belajar mahasiswa. Selain itu, persepsi mahasiswa terhadap lingkungan belajar berubah setiap mereka berpindah ke bagian lain. Menurut Patel dan Dauphinee (1985) dikutip dari Emilia (2008) yaitu lingkungan belajar yang berbeda akan memberikan pengalaman yang berbeda yang nantinya akan mempengaruhi perilaku belajar mahasiswa. Penyiapan lingkungan belajar klinik khususnya rumah sakit dalam pendidikan klinik akan lebih serius sehingga kualitas proses pendidikan menjadi bertambah baik, demikian juga lulusan yang di hasilkan menjadi semakin memiliki kompetensi yang profesional (Syahreni \& Waluyanti, 2007).

Berdasarkan penelitian terdahulu yang dilakukan oleh oleh Finn, Thorburn, dan King (2000) yang dikutip dari Syahreni dan Waluyanti (2007) ditemukan bahwa banyak mahasiswa yang mengalami kesulitan saat berhadapan dengan masalahmasalah nyata selama menjalani pembelajaran klinik. Penyebab masalah dalam menjalani pembelajaran klinik sangat bervariasi di antaranya karena mahasiswa baru pertama kalinya menghadapi pembelajaran klinik, pemahaman yang terbatas terhadap tugas profesi, lingkungan baru dan pengalaman pertama berinteraksi dengan pasien. Keberhasilan pembelajaran klinik dipengaruhi oleh kesiapan pengetahuan, mental, emosi dan ketersediaan lingkungan pembelajaran yang kondusif (Syahreni \& Waluyanti, 2007).

Menurut Sharif dan Masoumi (2005) lingkungan klinik rumah sakit merupakan satu-satunya sumber kecemasan terbesar bagi kalangan mahasiswa keperawatan. Masih menurut Sharif dan Masoumi (2005) para siswa keperawatan yang prakti klinik di rumah sakit akan mengalami kesulitankesulitan di awal praktik, hampir semua siswa mengalami cemas saat di awal praktik. Penyebab lainya siswa kecemasan dalam pengalaman klinik adalah kekhawatiran siswa tentang kemungkinan membahayakan pasien melalui kurangnya pengetahuan mereka. Hal ini di perkuat oleh Emilia (2008) menyatakan konteks pembelajaran praktik lebih tidak terstruktur dibanding perkuliahan. Oleh karenanya, mahasiswa mungkin lebih banyak menghadapi cemas, stress dan tekanan.

Menurut Yonge et al, (2002) dikutip dari Kevin, J (2006), pembelajaran klinik 
dapat memicu terjadinya kecemasan pada mahasiswa keperawatan selama pembelajaran klinik. Hal senada di ungkapkan oleh Moscaritolo (2009) yang dengan jelas menunjukkan bahwa identifikasi mahasiswa keperawatan terhadap lingkungan belajar klinis merupakan penyebab kecemasan dan stres. Mahasiswa menilai pembelajaran klinik sebagai pembelajaran keterampilan, seringkali mereka merasa frustasi apabila tidak memeproleh keterampilan yang tidak adekuat (Syahreni \& Waluyanti, 2007). Untuk itu, lingkungan klinis yang merupakan pembelajaran penting untuk mahasiswa keperawatan. Sayangnya, itu juga dapat menjadi sumber kecemasan bagi mahasiswa (Syahreni \& Waluyanti, 2007).

Secara umum, survey awal yang dilakukan peneliti terhadap mahasiswa program Ners PSIK UNAND pada siklus klinik (KMB, keperawatan anak, keperawatan maternitas, keperawatan gawat darurat, manajemen keperawatan) tanggapan mahasiwa terhadap lahan klinik mereka adalah yaitu mahasiswa merasa lebih cemas jika masuk siklus klinik (rumah sakit). Mahasiswa mengatakan pada lingkungan klinik rumah sakit banyaknya beban kerja klinik yang mereka dapatkan dibandingkan pada siklus lain, mahasiswa juga mengatakan pada lingkungan klinik rumah sakit $\mathrm{CI}$ ataupun staf perawat tidak memberikan hubungan yang posistif yang dapat memberikan umpan balik yang konstruktif. Selain itu, mahasiswa juga mengatakan pada siklus klinik hanya sebagian dapat mencapai tujuan belajar pada siklus tersebut.

Ada permasalahan yang ditemukan pada 10 orang mahasiswa program (A dan B) Ners PSIK UNAND pada siklus ke VIII yaitu KGD dan KMB lingkungan klinik di rumah sakit (RSUP. Dr. M. Djamil \& RS. Siti Rahmah) yang sedang melaksanakan pembelajaran praktik klinik keperawatan pada tanggal 2 Agustus 2011 yaitu mahasiswa merasa lebih tegang dalam belajar praktik dibandingkan dengan belajar teori dan pernah gagal lebih dari 2 kali dalam melakukan tindakan klinis (memasang infus) yaitu sebanyak $81 \%$. Mahasiswa khawatir jika akan masuk ke lahan praktik dengan lingkungan yang baru yaitu sebanyak 63\%. Mahasiswa tidak konsentrasi ketika melakukan tindakan perawatan tanpa didampingi pembimbing klinik dan panik ketika melakukan pengkajian keperawatan langsung kepada pasien yaitu sebanyak $36 \%$.

Penelitian ini bertujuan untuk mengetahui hubungan antara lingkungan belajar klinik dengan tingkat kecemasan pada pembelajaran klinik mahasiswa program Ners.

\section{METODE}

Jenis penelitian yang digunakan adalah penelitian korelatif dengan pendekatan cross sectional. Populasi dalam penelitian ini adalah semua mahasiswa program Ners PSIK UNAND tahun 2011/2012 yang yang sedang mengikuti praktik pembelajaran tahap profesi Ners di klinik (rumah sakit) yaitu berjumlah 69 orang. Alat ukur yang digunakan instrumen SECEE untuk mengukur lingkungan belajar klinik dan instrumen DASS untuk mengukur tingkat kecemasan. Penelitian ini menggunakan teknik pengambilan sampel yaitu dengan metode total sampling. Uji statistik yang digunakan adalah Spearman Rank.

\section{HASIL DAN PEMBAHASAN}

Hasil uji Spearman Rank dengan nilai $\mathrm{p}=0,000$ bahwa terdapat hubungan yang bermakna antara lingkungan belajar klinik dengan tingkat kecemasan. Nilai korelasi Spearman's rho adalah -0,769, menunjukan korelasi yang kuat dengan arah korelasi negatif yaitu berlawanan arah dimana semakin buruk lingkungan belajar klinik akan semakin meningkatkan kecemasan 
Tabel 1 Karakteristik Responden Mahasiswa Program Ners PSIK FK-UNAND Selama Dalam Pembelajaran Klinik

\begin{tabular}{clcc}
\hline NO & \multicolumn{1}{c}{ Data Demografi } & Jumlah $(\mathbf{n = 6 9 )}$ & Persentase \\
\hline 1. & Gender & 9 & 13 \\
& a. Laki-laki & 60 & 87 \\
\hline b. Perempuan & Program & 42 & 61 \\
& a. A & 27 & 39 \\
\hline b. B & & \\
\hline Umur & 20-30 tahun & 63 & 91,3 \\
& 31-40 tahun & 6 & 8,7 \\
\hline 4. & Siklus & 14 & 21 \\
& a. Kep. Anak & 21 & 30 \\
& b. Kep. Medikal Bedah & 13 & 19 \\
& c. Kep. Maternitas & 21 & 30 \\
d. Manajemen & & \\
$\quad$ Keperawatan & & 29 \\
\hline 5. & Lama Siklus & 7 hari & 29 \\
& a. Kep. Anak & 7 hari & 8,3 \\
b. Kep. Medikal Bedah & 2 hari & 35 \\
c. Kep. Maternitas & 7 hari & \\
d. Manajemen & & \\
& $\quad$ Keperawatan &
\end{tabular}

Berdasarkan tabel demografi di atas, didapatkan dari 69 orang mahasiswa, lebih dari separuh $(87 \%)$ berjenis kelamin perempuan, dan $(91,3 \%)$ berumur $20-30$ tahun, serta berasal dari program A $(61 \%)$. Jumlah mahasiswa terbanyak $(30 \%)$ pada siklus Kep. Medikal Bedah dan Manjemen Keperawatan. Pada siklus Kep. Anak, Kep. Medikal Bedah dan Manajemen Keperawatan, sudah terlaksana selama 7 hari, sedangkan pada siklus Kep. Maternitas baru terlaksana selama 2 hari.

Tabel 2 Hubungan Lingkungan Belajar Klinik Dengan Tingkat Kecemasan Pada Mahasiswa Program Ners PSIK FK-UNAND Dalam Pembelajaran Klinik

\begin{tabular}{ccccccccccccc}
\hline $\begin{array}{c}\text { No. Lingkungan } \\
\text { Belajar } \\
\text { Klinik }\end{array}$ & \multicolumn{4}{c}{ Tingkat Kecemasan } & & Total & $\begin{array}{c}\text { P } \\
\text { Spearma }\end{array}$ \\
\cline { 3 - 11 } & Berat & $\%$ & Sedang & $\%$ & Ringan & $\%$ & F & $\%$ & & Value & n's rho \\
\hline 1. & Buruk & 2 & 2,9 & 30 & 43,5 & 2 & 2,9 & 34 & 49,3 & & \\
2. & Cukup & 0 & 0 & 9 & 13 & 20 & 29 & 29 & 42 & 0,000 & $-0,769$ \\
3. & Baik & 0 & 0 & 0 & 0 & 6 & 8,7 & 6 & 8,7 & & \\
& Total & 2 & 2,9 & 39 & 56,5 & 28 & 40,6 & 69 & 100 & & \\
\hline
\end{tabular}

Berdasarkan tabel di atas, didapatkan dari 34 mahasiswa yang menyatakan lingkungan klinik buruk, 30 mahasiswa memiliki tingkat kecemasan sedang $(43,5 \%)$ dan didapatkan dari 29 mahasiswa yang menyatakan lingkungan 
klinik sedang, 20 mahasiswa memiliki tingkat kecemasan ringan (29\%). Hasil uji Spearman Rank dengan nilai $\mathrm{p}=0,000$ bahwa terdapat hubungan yang bermakna antara lingkungan belajar klinik dengan tingkat kecemasan. Nilai korelasi Spearman's rho adalah -0,769, menunjukan korelasi yang kuat dengan arah korelasi negatif yaitu berlawanan arah dimana semakin buruk lingkungan belajar klinik akan semakin meningkatkan kecemasan.

\section{Lingkungan belajar klinik buruk}

lebih banyak (49,3\%) dibandingkan lingkungan belajar yang cukup dan baik. Didapatkan hasil dari mahasiswa program A (61\%), lebih banyak (45\%) menyatakan lingkungan klinik yang buruk dibandingkan program B (27\%). Kurangnya interaksi antara mahasiswa dan perawat ruangan yang seharusnya dapat didekati, dapat mendengarkan dengan penuh perhatian, serta dorongan untuk saling menghormati satu sama lain, serta umpan balik yang diharapkan mahasiswa sehingga proses belajar selama dalam melaksanakan pembelajaran klinik tidak berajalan dengan baik. Mahasiswa dapat memperoleh keterampilan melalui interaksi mahasiswa dengan staf perawat baik itu KARU, CI maupun perawat ruangan yang menjadi role model dan memberikan perilaku yang diperlukan.

Menurut hasil penelitian fenomenologi Syahreni dan Waluyanti (2007) pada pengalaman mahasiswa keperawatan program reguler dalam pembelajaran klinik, bahwa lingkungan belajar dibangun melalui interaksi atara pengajar dan mahasiswa, dalam membentuk hubungan interpersonal dengan peserta didik, pengajar harus bersifat hangat dan terbuka, sangat berpusat pada peserta didik dan dapat diprediksi. Menurut Reilly dan Oermann (2002) pengajaran dalam pembelajaran klinik berlangsung dalam suasana yang penuh rasa percaya, otentik, perhatian dimana peserta didik mendapat dukungan ketika mereka memasuki pengalaman belajar yang mungkin berisiko dan melibatkan cara baru penggunaan diri.
Mahasiswa belajar melalui mengamati, meniru, dan mempraktikan dalam bentuk situasi yang nyata.

Untuk mengetahui hubungan antara variabel independen dan dependen, dilakukan secara komputerisasi dengan uji Spearman Rank. Dari tabel 1 didapatkan dari 34 mahasiswa yang menyatakan lingkungan klinik buruk, 30 mahasiswa memiliki tingkat kecemasan sedang $(43,5 \%)$ dan didapatkan dari 29 mahasiswa menyatakan lingkungan klinik sedang, 20 mahasiswa memiliki tingkat kecemasan ringan (29\%). Hasil uji Spearman Rank didapatkan nilai $\mathrm{p}=0,000$ dan nilai Spearman's rho=-.769 yang menunjukan bahwa terdapat hubungan yang bermakna antara lingkungan belajar klinik dengan tingkat kecemasan dan terdapat korelasi yang kuat dengan arah korelasi negatif yaitu berlawanan arah dimana semakin buruk lingkungan belajar klinik akan semakin meningkatkan kecemasan.

Menurut hasil penelitian Syahreni \& Waluyanti (2007) salah satu sumber kecemasan mahasiswa keperawatan dalam menghadapi pembelajaran klinik adalah rasa takut gagal yang dapat mengancam nyawa seseorang yang kemudian diiringi oleh kehilangan harga diri. Berdasarkan karakteristik responden, mahasiswa program A $(61 \%)$ lebih banyak mengalami tingkat kecemasan sedang. Mahasiswa program A lebih banyak mengalami kekhawatiran selama dalam pembelajaran klinik (68\%), hal tersebut karena kurangnya bimbingan serta dukungan dari perawat ruangan dalam mempelajari keterampilan (63\%). Menurut Locken dan Norberg (2007) telah ditemukan bahwa penyebab utama kecemasan mahasiswa adalah rasa takut membuat kesalahan selama di lahan praktik dalam melakukan prosedur klinis.

Meningkatnya kecemasan merupakan respon peserta didik terhadap evaluasi lingkungan tersebut, lingkungan klinik yang buruk tidak akan mendukung pembelajaran klinik serta tidak akan membentuk suasana belajar yang mendukung. Menurut Reilly dan Oermann (2002) lingkungan 
klinik kaya akan pengalaman belajar, tetapi lingkungan yang kurang mendukung akan mematahkan semangat belajar peserta didik untuk mencari pengalaman dan akibatnya banyak kesempatan untuk maju hilang. Kuatnya korelasi antara kedua variabel menunjukkan persepsi mahasiswa terhadap lingkungan belajar klinik akan memberikan makna yang kuat pada interaksi mahasiswa yang unik dalam menghadapi lingkungan pembelajaran di rumah sakit. Hal ini akan mempengaruhi pendekatan belajar mahasiswa dan keberhasilan belajar.

Mahasiswa yang berada pada siklus Keperawatan Anak, Keperawatan Medikal Bedah dan Manajemen Keperawatan, sudah terlaksana selama 7 hari, sedangkan pada siklus Keperawatan Maternitas baru terlaksana selama 2 hari. Mahasiswa pada siklus Keperawatan Maternitas (84\%) dan Keperawatan Anak lebih banyak (92\%) mengalami kecemasan sedang. Menurut Lazarus (1999) kecemasan didasarkan atas kondisi emosional individu. Kondisi emosi yang sifatnya sementara, yang timbul apabila individu dihadapkan pada situasi tertentu. Reaksi emosi ini bervariasi intensitasnya serta berfluktuasi sepanjang waktu. Gejala kecemasan ini akan tampak selama situasi tersebut masih ada dan tidak tergantung berapa lama individu berada pada suatu lingkungan atau situasi tertentu. Sedangkan A-trait lebih stabil dibandingkan A-state, terutama kecenderungan kecemasannya pada tiap orang. Kecemasan dipandang sebagai sesuatu yang sudah tetap ada pada individu.

Pada siklus Keperawatan Anak, responden cenderung lebih banyak menyatakan lingkungan belajar klinik buruk $(86 \%)$ terlihat pada item kuesioner "perawat ruangan melayani saya sebagai mahasiswa keperawatan selayaknya bagian dari tim mereka dan perawat ruanganmemberikan bimbingan yang cukup selama pembelajaran klinik", responden lebih banyak (87\%) memilih tidak setuju. Menurut Reilly (2002) selama proses pembelajaran klinik mahasiswa dapat mempelajari praktik keperawatan yang sesungguhnya melalui pembimbing klinik, maupun perawat ruangan yang dapat menjadi role model yang dapat ditiru oleh mahasiswa. Sayangnya, peran model ini sering tidak terfasilitasi oleh lingkungan praktik klinik. Menurut hasil penelitian Cross (1995) menekankan, tenaga pendidik di bidang klinik memiliki peran vital untuk menjamin kualitas pendidikan klinik. Proses pembelajaran pada suatu tempat praktik klinik yang memungkinkan pembimbing klinik, perawat ruangan, mahasiswa dan pasien saling berinteraksi secara langsung atau satu sama lain.

\section{KESIMPULAN DAN SARAN}

Semakin buruk lingkungan klinik akan semakin meningkatkan kecemasan. Agar dapat mengaplikasikan metode mentorship di setiap ruangan tempat praktik selama pembelajaran klinik sehingga dapat meningkatkan kepercayaan, harga diri, kepercayaan diri serta pencapaian kompetensi mahasiswa, diharapkan sebelum memasuki siklus/rotasi klinik dapat mengkaji khususnya disetiap fase, terutama fase prainteraksi untuk mengkaji perasaan, fantasi dan ketakutan sehingga kesadaran kesiapan peserta didik dan menimalkan pengaruh kelemahan yang ada didalam diri peserta didik.

\section{DAFTAR PUSTAKA}

Cross, L. (2004). Learning in the classroom environment. Journal Teacher Education, 28(6), 51-52.

Emilia, O. (2008). Kompetensi dan lingkungan belajar klinik di rumah sakit. Yogyakarta: Gajah Mada University Press.

Kevin, J. (2006). Problem in the supervision and assessment of student nurse: can clinical placemen be improved. Contemporary Nurse, 22(1), 36-45.

Lazarus, R. (1999). Introduce level of anxiety. Journal of Advanced Nursing, 49(9), 2290-2300.

Locken \& Norberg. (2007). Reduced anxiety improves learning ability of nursing students through utilization of 
mentoring triads. Journal of Nursing Education, 2(2), 69-73.

Moscaritolo, L.M. (2009). Interventional strategies to decrease nursing student anxiety in the clinical learning environment. The Journal Of Nursing Education, 48(1), 17-23.

Reilly, D.E \& Oermann, M. (2002). Pengajaran klinis dalam pendidikan keperawatan (Edisi 2). Jakarta: Buku Kedokteran EGC.
Sharif, F \& Masoumi, S. (2005). A qualitative study of nursing student experiences of clinical practice. Southern Online Journal of Nursing Research, 1(23), 1445-1489..

Syahreni, E \& Waluyanti, F.T. (2007). Pengalaman mahasiswa S1 keperawatan program reguler dalam pembelajaran klinik. Jurnal Keperawatan Indonesia. 11(2), 47-53. 